\title{
Synthesis of Perfluorinated Heterocyclic Compounds Having a Long Alkyl Chain Functionality by 1,3-Dipolar Cycloaddition
}

\author{
Chan Woo Lee, ${ }^{\dagger, * *}$ Ho Yun Hwang, Joo Yuen Park, ${ }^{\ddagger}$ and Ki-Whan Chi ${ }^{\ddagger} *$ \\ †Department of Chemistry, Hanyang University, Seoul 133-791,Korea. ${ }^{*} E-m a i l:$ lcw@hanyang.ac.kr, lcw5113@ulsan.ac.kr \\ ${ }^{\star}$ Department of Chemistry, University of Ulsan, Ulsan 680-749, Korea \\ Received April 29, 2009, Accepted February 24, 2010
}

\begin{abstract}
Regioselective perfluorinated isoxazolidine (5 and 7), isoxazoline (9) and 1,2-addition products (6 and 8 ) having a long alkyl chain functionality have been prepared by 1,3-dipolar cycloaddition between a 1,3-dipole (NH-nitrone or nitrile oxide) and dipolarophile (perfluoro-2-methyl-2-pentene or styrene), respectively. Interestingly, unusual extended conjugated form of isoxazoline adduct (10) was obtained by dehydrofluorinated reaction from the corresponding perfluorinated isoxazoline adduct (9) which was derived from cycloadition between the perfluorinated long alkyl nitrile oxide 1,3-diplole and styrene olefin. This synthetic methodology of heterocyclic compound having a long alkyl chain functionality is useful for the designing of synthetic strategy and potential self-assembled monolayers (SAM) application. These derivatives were characterized by IR, ${ }^{1} \mathrm{H}$ and ${ }^{19} \mathrm{~F}$ NMR, and MASS analysis.
\end{abstract}

Key Words: Perfluorinated long alkyl, Isoxazoline, Isoxazolidine, Cycloaddition

\section{Introduction}

The synthesis of specifically fluorinated long-chain $\alpha, \omega$-functionalized hydrocarbons remains a challenging problem for the study of self-assembled monolayers (SAM). The preparation, based on the SAM technique, of organized monomer films from these molecules offers the opportunity to study fundamental properties of (per)fluorinated interfaces, such as wetting, adhesion, and friction. The influence of the length of the fluorinated and hydrogenated segments on such properties is of great interest in Langmuir-Blodgett and self-assembly techniques. ${ }^{1,2}$ The synthesis of fluoro-substituted heterocycles has received a great deal of attention in recent years, because the special biological activity of many of these compounds makes them effective as antifungal, antiviral, and antitumor agents. ${ }^{3,4}$ Although many perfluorinated linear and cyclic organic compounds are either commercially available or have been reported in the literatures such as perfluorinated oxadiazoles, ${ }^{5}$ isoxazolidine and isoazole, ${ }^{6}$ reports of the synthesis of perfluorinated long alkyl chain heterocyclic compounds are relatively rare. Considering the significance of the perfluorinated organic compounds and their relative rarity, it is important to develop methodologies for the regioselective preparation of perfluorinated heterocycles. Furthermore, it is well known that these heterocycles are also versatile templates in organic synthesis, since their $\mathrm{N}-\mathrm{O}$ bond can be reductively cleaved, affording open-chain compounds such as hydroxyl ketones and 1,3-amino alcohols. ${ }^{7}$

Recently, we reported the synthesis of regioselective isoxazolidine derivatives derived from cycloaddition reactions between NH-nitrones and perfluorinated olefin, perfluoro-2-methyl-2-pentene, under mild condition. ${ }^{8}$ The evaluation of this synthetic method led us to predict that long alkyl chain perfluorinated dipoles or dipolarophiles might provide an improved synthetic method for the preparation of various heterocyclic compounds allowing their SAM chemistry. Herein, we report a facile approach to the synthesis of terminally perfluorinated long alkyl chain isoxazolines and isoxazolidines based on a 1,3-dipolar cycloaddition reaction.

\section{Experimental Section}

General procedures. All chemicals were of the best grade available from Aldrich Chemical Co. and were used without further purification. NMR spectra were recorded on a Bruker AM-300 (MHz) spectrometer with TMS as an internal standard. FT-IR spectra were recorded using a Thermo Mattson Satellite spectrometer. FAB Mass spectra (MS) were measured with a JMS-HX/HX110A.

Preparation of 4-(nonyloxy)benzaldoxime (1) and 4-(decyloxy)benzaldoxime (2). Solution of 4-hydroxy benzaldehyde $(0.1 \mathrm{~mol})$ and $\mathrm{K}_{2} \mathrm{CO}_{3}(0.15 \mathrm{~mol})$ in $200 \mathrm{~mL}$ of DMF was heated for $30 \mathrm{~min}$ at $50{ }^{\circ} \mathrm{C}$. To this solution was added 1-brormononane $(0.2 \mathrm{~mol})$ or 1 -bromodecane $(0.2 \mathrm{~mol})$ dropwise and the resulting mixture was heated for $8 \mathrm{~h}$ at $70^{\circ} \mathrm{C}$. After removal of DMF under reduced pressure, the residue was dissolved in chloroform and solution was filtered. The filtrate was concentrate under reduced pressure. The residue was subjected to column chromatography to give the 4-(nonyloxy)benzaldehyde (89\%) and 4-(decyloxy)benzaldehyde (91\%), respectively. The 4-(nonyloxy)benzaldehyde and 4-(decyloxy)benzaldehyde are quantitatively converted into the corresponding 4-(nonyloxy)benzaldoxime (1) and 4-(decyloxy)benzaldoxime (2) by treatment of hydroxylamine.

Preparation of $1 \mathrm{H}, 1 \mathrm{H}, 2 \mathrm{H}, 2 \mathrm{H}$-perfluoro-1-nonanaldoxime (4). Solution of $1 H, 1 H, 2 H, 2 H$-perfluoro-1-decanol ( $0.01 \mathrm{~mol})$ and pyridinium chlorochromate (PCC, $0.015 \mathrm{~mol}$ ) in $50 \mathrm{~mL}$ of $\mathrm{CH}_{2} \mathrm{Cl}_{2}$ was reacted at room temperature for $24 \mathrm{~h}$. The mixture was washed with water and the residue was subjected to column chromatography to give the $1 H, 1 H, 2 H, 2 H$-perfluoro1-nonanal $(3,57 \%)$. The $1 H, 1 H, 2 H, 2 H$-perfluoro-1-nonanal is quantitatively converted into the corresponding $1 \mathrm{H}, 1 \mathrm{H}, 2 \mathrm{H}$, $2 \mathrm{H}$-perfluoro-1-nonanalcoxime (4) by treatment of hydroxyl- 
amine.

Cycloaddition between 4-(nonyloxy)benzaldoxime (1) or 4-(decyloxy)benzaldoxime (2) and perfluoro-2-methyl-2-pentene. The solution of 4-(nonyloxy)benzaldoxime (1, $0.05 \mathrm{~mol})$ or 4-(decyloxy)benzaldoxime $(2,0.05 \mathrm{~mol})$ and perfluoro-2methyl-2-pentene $(0.5 \mathrm{~mol})$ in ethanol $(50 \mathrm{~mL})$ was reacted under room temperature for $12 \mathrm{~h}$. After reaction, the solvent and excess perfluoro-2-methyl-2-pentene were evaporated to dryness. The crude products were purified by silica gel column chromatography to give the corresponding product 5 (39\%), 6 $(54 \%), 7(35 \%)$, and $8(51 \%)$, respectively.

Cycloaddition between $1 \mathrm{H}, 1 \mathrm{H}, 2 \mathrm{H}, 2 \mathrm{H}$-perfluoro-1-nonanaldoxime (4) and styrene. The solution of $1 H, 1 H, 2 H, 2 H$-perfluoro-1-nonanaldoxime $(3,0.05 \mathrm{~mol})$ and sodium hyphochlorite solution $(0.01 \mathrm{~mol})$ in chloroform was reacted at room temperature for $30 \mathrm{~min}$, and then the resulting nitrile oxide intermediate was obtained. The in situ generated intermediate in chloroform was reacted with styrene $(0.5 \mathrm{~mol})$ to give the corresponding isoxazoline $9(51 \%)$ and $10(22 \%)$ in a high yield, respectively.

Spectral data for compound 1: Colorless liquid; ${ }^{1} \mathrm{H}$ NMR $\left(\mathrm{CDCl}_{3}, 300 \mathrm{MHz}\right) \delta 0.98\left(\mathrm{t}, 3 \mathrm{H}, \mathrm{CH}_{3}\right), 1.2-1.6\left(\mathrm{~m}, 12 \mathrm{H},\left(\mathrm{CH}_{2}\right)_{6}\right)$, $1.77\left(\mathrm{~m}, 2 \mathrm{H}, \mathrm{OCH}_{2} \mathrm{CH}_{2}\right), 3.95\left(\mathrm{t}, 2 \mathrm{H}, \mathrm{OCH}_{2}\right), 6.88(\mathrm{~d}, 2 \mathrm{H}$, aromatic), 7.46 (d, 2H, aromatic), $8.06(\mathrm{~s}, 1 \mathrm{H}, \mathrm{CH}=\mathrm{N}), 10.7$ (br, $1 \mathrm{H}, \mathrm{NOH}) ;{ }^{13} \mathrm{C} \mathrm{NMR}\left(\mathrm{CDCl}_{3}\right) \delta 16.9\left(\mathrm{CH}_{3}\right), 22.8\left(\mathrm{CH}_{2}\right), 26.1$ $\left(\mathrm{CH}_{2}\right), 29.1\left(\mathrm{CH}_{2}\right), 29.4\left(\mathrm{CH}_{2}\right), 29.8\left(\mathrm{CH}_{2}\right), 68.3\left(\mathrm{CH}_{2}\right), 103.7$ (aromatic), 114.9 (aromatic), 119.5 (aromatic), 134.1 (aromatic), $162.6(\mathrm{CH}=\mathrm{N})$; IR $\left(\mathrm{cm}^{-1}\right)$ 3300, 2950, 1630, 1495, 1170.

Spectral data for compound 2: Colorless liquid; ${ }^{1} \mathrm{H}$ NMR $\left(\mathrm{CDCl}_{3}, 300 \mathrm{MHz}\right) \delta 0.89\left(\mathrm{t}, 3 \mathrm{H}, \mathrm{CH}_{3}\right), 1.2-1.5\left(\mathrm{~m}, 14 \mathrm{H},\left(\mathrm{CH}_{2}\right)_{7}\right)$, $1.79\left(\mathrm{~m}, 2 \mathrm{H}, \mathrm{OCH}_{2} \mathrm{CH}_{2}\right), 3.98\left(\mathrm{t}, 2 \mathrm{H}, \mathrm{OCH}_{2}\right), 6.90$ (d, $2 \mathrm{H}$, aromatic), 7.48 (d, 2H, aromatic), $8.09(\mathrm{~s}, 1 \mathrm{H}, \mathrm{CH}=\mathrm{N}), 10.7$ (br, $1 \mathrm{H}, \mathrm{NOH}) ;{ }^{13} \mathrm{C} \mathrm{NMR}\left(\mathrm{CDCl}_{3}\right) \delta 17.1\left(\mathrm{CH}_{3}\right), 23.1\left(\mathrm{CH}_{2}\right), 26.4$ $\left(\mathrm{CH}_{2}\right), 30.1\left(\mathrm{CH}_{2}\right), 30.3\left(\mathrm{CH}_{2}\right), 30.7\left(\mathrm{CH}_{2}\right), 30.9\left(\mathrm{CH}_{2}\right), 68.8$ $\left(\mathrm{CH}_{2}\right), 103.9$ (aromatic), 115.5 (aromatic), 120.1 (aromatic), 134.5 (aromatic), $162.9(\mathrm{CH}=\mathrm{N})$; IR $\left(\mathrm{cm}^{-1}\right)$ 3300, 2940, 1625, 1482, 1165.

Spectral data for compound 3: ${ }^{1} \mathrm{H}-\mathrm{NMR}\left(300 \mathrm{MHz}, \mathrm{CD}_{3} \mathrm{OD}\right)$ $\delta 3.3\left(\mathrm{~m}, 2 \mathrm{H}, \mathrm{CH}_{2}\right), 6.93(\mathrm{~s}, \mathrm{CHO}) ;{ }^{19} \mathrm{~F}-\mathrm{NMR}\left(\mathrm{CD}_{3} \mathrm{OD}\right) \delta-82.43$ $\left(\mathrm{CF}_{3}\right),-113.98,-122.99,-123.82,-124.77$, and $127.38\left(\mathrm{CF}_{2}\right)$; IR $\left(\mathrm{cm}^{-1}\right)$ 1720, 1240 (CF), 1230.

Spectral data for compound $4:{ }^{1} \mathrm{H}-\mathrm{NMR}\left(300 \mathrm{MHz}, \mathrm{CD}_{3} \mathrm{OD}\right)$ $\delta 3.52\left(\mathrm{~d}, 2 \mathrm{H}, \mathrm{CH}_{2}\right), 6.60(\mathrm{~s}, 1 \mathrm{H}, \mathrm{CH}=\mathrm{N}), 7.3(\mathrm{~s}, 1 \mathrm{H}, \mathrm{CH}=\mathrm{N})$, $8.59 \mathrm{br}, 1 \mathrm{H}, \mathrm{NOH}) ;{ }^{19} \mathrm{~F}-\mathrm{NMR}\left(\mathrm{CD}_{3} \mathrm{OD}\right) \delta-82.36\left(\mathrm{CF}_{3}\right),-122.18$, $-122.94,-123.78,-124.77$, and $127.34\left(\mathrm{CF}_{2}\right)$; IR $\left(\mathrm{cm}^{-1}\right) 3500$, 1610, 1340, 1230 (CF), 1210.

Spectral data for compound 5: White crystals, mp $49{ }^{\circ} \mathrm{C}$; ${ }^{1} \mathrm{H}-\mathrm{NMR}\left(300 \mathrm{MHz}, \mathrm{CDCl}_{3}\right) \delta 0.86\left(\mathrm{t}, 3 \mathrm{H}, \mathrm{CH}_{3}\right), 1.28-1.47(\mathrm{~m}$, $\left.12 \mathrm{H},\left(\mathrm{CH}_{2}\right)_{6}\right), 1.78\left(\mathrm{ddd}, 2 \mathrm{H}, \mathrm{OCH}_{2} \mathrm{CH}_{2}\right), 3.95\left(\mathrm{t}, 2 \mathrm{H}, \mathrm{OCH}_{2}\right)$, $5.06(\mathrm{~d}, 1 \mathrm{H},(1 S, 3 S), \mathrm{CHNH})$ and $5.46(\mathrm{~d}, 1 \mathrm{H},(1 R, 3 S) \mathrm{CHNH})$ $((1 S, 3 S):(1 R, 3 S)=4: 6), 6.93(\mathrm{~d}, 2 \mathrm{H}$, aromatic $), 7.28(\overline{\mathrm{d}}, 2 \mathrm{H}$, aromatic), 7.38 (br, $1 \mathrm{H}, \mathrm{NH}) ;{ }^{19} \mathrm{~F}-\mathrm{NMR}\left(\mathrm{CDCl}_{3}\right) \delta-58.89$, -59.24, 60.78 and -64.32 ( $\left.\mathrm{CF}_{3}\right),-79.81,80.07\left(\mathrm{CF}_{2} \mathbf{C F}_{3}\right),-115.7$, $-118.79,-118.91,-119.8$ (CF), $-120.03,-121.43,-121.77$, -122.81 , and $-123.86\left(\mathrm{CF}_{2}\right)$; IR $\left(\mathrm{cm}^{-1}\right) 3200(\mathrm{NH}), 2997,1620$, 1250 (CF), 1203.

Spectral data for compound 6: White crystals, mp $49{ }^{\circ} \mathrm{C}$; ${ }^{1} \mathrm{H}-\mathrm{NMR}\left(300 \mathrm{MHz}, \mathrm{CDCl}_{3}\right) \delta 0.93\left(\mathrm{t}, 3 \mathrm{H}, \mathrm{CH}_{3}\right), 1.32-1.77(\mathrm{~m}$, $\left.12 \mathrm{H},\left(\mathrm{CH}_{2}\right)_{6}\right), 1.86\left(\mathrm{ddd}, 2 \mathrm{H}, \mathrm{OCH}_{2} \mathrm{CH}_{2}\right), 4.05$ (t, 2H, $\left.\mathrm{OCH}_{2}\right)$, $4.61(\mathrm{qqd}, 1 \mathrm{H}$, trans-CH) and $4.83(\mathrm{qqd}, 1 \mathrm{H}$, cis- $\mathrm{CH})$ (trans : cis $=7: 3), 6.95(\mathrm{dd}, 2 \mathrm{H}$, aromatic $), 7.56(\mathrm{dd}, 2 \mathrm{H}$, aromatic $)$, $7.76(\mathrm{~d}, 1 \mathrm{H}$, cis- $\mathrm{CH}=\mathrm{NH}), 8.22(\mathrm{~s}, 1 \mathrm{H}$, trans $-\mathrm{CH}=\mathrm{NH}) ;{ }^{19} \mathrm{~F}-$ NMR $\left(\mathrm{CDCl}_{3}\right) \delta-59.75,-60.06,-60.91$ and $-61.01\left(\mathrm{CF}_{3}\right)$, $-79.69,-79.85\left(\mathrm{CF}_{2} \mathbf{C F}_{3}\right),-112.39,-114.54,-120.12,-121.19$ (CF), -121.23, -121.43, and -122.51 $\left(\mathrm{CF}_{2}\right)$; IR $\left(\mathrm{cm}^{-1}\right) 2997$, 2990, 1625, 1250 (CF), 1230.

Spectral data for compound 7: White crystals, mp $51{ }^{\circ} \mathrm{C}$; ${ }^{1} \mathrm{H}-\mathrm{NMR}\left(300 \mathrm{MHz}, \mathrm{CDCl}_{3}\right) \delta 0.88\left(\mathrm{t}, 3 \mathrm{H}, \mathrm{CH}_{3}\right), 1.29-1.47$ (m, $\left.14 \mathrm{H},\left(\mathrm{CH}_{2}\right)_{7}\right), 1.80\left(\mathrm{ddd}, 2 \mathrm{H}, \mathrm{OCH}_{2} \mathrm{CH}_{2}\right), 3.95\left(\mathrm{t}, 2 \mathrm{H}, \mathrm{OCH}_{2}\right)$, $5.07(\mathrm{~d}, 1 \mathrm{H},(1 S, 3 S), \mathrm{CHNH})$ and $5.46 \overline{\mathrm{d}}, 1 \mathrm{H},(1 R, 3 S)((1 S, 3 S)$ : $(1 R, 3 S)=4: 6), \mathrm{CHNH}), 6.96(\mathrm{~d}, 2 \mathrm{H}$, aromatic $), 7.24(\mathrm{~d}, 2 \mathrm{H}$, aromatic), $7.39(\mathrm{br}, 1 \mathrm{H}, \mathrm{NH}) ;{ }^{19} \mathrm{~F}-\mathrm{NMR}\left(\mathrm{CDCl}_{3}\right) \delta-58.93$, $-59.24,-59.30$, and $-64.35\left(\mathrm{CF}_{3}\right),-79.87,-80.14\left(\mathrm{CF}_{2} \mathbf{C F}_{3}\right)$, $-115.7,-118.81,-118.93,-119.9$ (CF), -121.14, -122.863, -123.98 , and $-123.46\left(\mathrm{CF}_{2}\right)$; IR $\left(\mathrm{cm}^{-1}\right) 3200(\mathrm{NH}), 2990,1630$, 1250 (CF), 1203.

Spectral data for compound 8: White crystals, mp $51{ }^{\circ} \mathrm{C}$; ${ }^{1} \mathrm{H}-\mathrm{NMR}\left(300 \mathrm{MHz}, \mathrm{CDCl}_{3}\right) \delta 0.91\left(\mathrm{t}, 3 \mathrm{H}, \mathrm{CH}_{3}\right), 1.30-1.72$ $\left(\mathrm{m}, 12 \mathrm{H},\left(\mathrm{CH}_{2}\right)_{7}\right), 1.84$ (ddd, $\left.2 \mathrm{H}, \mathrm{OCH}_{2} \mathrm{CH}_{2}\right), 4.03$ (t, $2 \mathrm{H}$, $\left.\mathrm{OCH}_{2}\right), 4.58$ (qqd, $1 \mathrm{H}$, trans- $\left.\mathrm{CH}\right)$ and $4.81(\mathrm{qqd}, 1 \mathrm{H}$, cis- $\mathrm{CH})$ (trans : cis =7:3), 6.92 (dd, 2H, aromatic), 7.53 (dd, $2 \mathrm{H}$, aromatic), $7.73(\mathrm{~d}, 1 \mathrm{H}$, cis- $\mathrm{CH}=\mathrm{NH}), 8.20(\mathrm{~s}, 1 \mathrm{H}$, trans $-\mathrm{CH}=\mathrm{NH})$; ${ }^{19} \mathrm{~F}-\mathrm{NMR}\left(\mathrm{CDCl}_{3}\right) \delta-59.68,-59.92,-60.81$ and $-60.98\left(\mathrm{CF}_{3}\right)$, $-79.89,-79.91\left(\mathrm{CF}_{2} \mathbf{C F}_{3}\right),-113.31,-114.50,-120.62,-121.29$ (CF), -121.63, -121.71, and $-122.49\left(\mathrm{CF}_{2}\right)$; IR $\left(\mathrm{cm}^{-1}\right)$ 2990, 2897, 1625, 1250 (CF), 1230.

Spectral data for compound 9: White crystals, mp $78{ }^{\circ} \mathrm{C}$; ${ }^{1} \mathrm{H}-\mathrm{NMR}\left(300 \mathrm{MHz}, \mathrm{CDCl}_{3}\right) \delta 3.05\left(\mathrm{dd}, 1 \mathrm{H}, \mathrm{CH}_{2}\right), 3.47$ (dd, $\left.1 \mathrm{H}, \mathrm{CH}_{2}\right), 3.28\left(\mathrm{t}, 2 \mathrm{H}, \mathrm{CF}_{2} \mathrm{CH}_{2}\right), 5.66(\mathrm{dd}, 1 \mathrm{H}, \mathrm{CH}), 7.31-739$ (m, 5H, aromatic); ${ }^{19} \mathrm{~F}-\mathrm{NMR}\left(\mathrm{CDCl}_{3}\right) \delta-82.49\left(\mathrm{CF}_{3}\right),-108.43$, $-113.37,-115.40,-123.68,-123.89,-124.58$, and $127.47\left(\mathrm{CF}_{2}\right)$; IR $\left(\mathrm{cm}^{-1}\right)$ 2990, 2890, 1630, 1245 (CF), 1237; FAB-MS ( $\left.\mathrm{m} / \mathrm{z}\right)$ $570.005\left(\mathrm{M}^{+}+1\right)$ 579.09, 562.40, 473.81, 104.35, 78.39.

Spectral data for compound 10: White crystals, $\mathrm{mp} 82{ }^{\circ} \mathrm{C}$; ${ }^{1} \mathrm{H}-\mathrm{NMR}\left(300 \mathrm{MHz}, \mathrm{CDCl}_{3}\right) \delta 3.27\left(\mathrm{dd}, 1 \mathrm{H}, \mathrm{CH}_{2}\right), 3.51(\mathrm{dd}, 1 \mathrm{H}$, $\left.\mathrm{CH}_{2}\right), 5.51$ (dd, $\left.1 \mathrm{H}, \mathrm{CH}\right), 6.55(\mathrm{~d}, 1 \mathrm{H}$, trans, $\mathrm{CH}=\mathrm{C}), 7.30-7.38$ (m, 5H, aromatic); ${ }^{19} \mathrm{~F}-\mathrm{NMR}\left(\mathrm{CDCl}_{3}\right) \delta-82.58\left(\mathrm{CF}_{3}\right),-114.71$, $-117.60,-122.58,-123.77,-124.58$, and $-127.50\left(\mathrm{CF}_{2}\right)$; IR $\left(\mathrm{cm}^{-1}\right)$ 2990, 2890, 1650, $1255(\mathrm{CF}), 1240$; FAB-MS $(\mathrm{m} / \mathrm{z})$ 559.006 $\left(\mathrm{M}^{+}+1\right)$, 559.91, 529.36, 453.69, 14.38, 78.40.

\section{Results and Discussion}

Our exploratory efforts began with the preparation of 4(nonyloxy)benzaldoxime (1) and 4-(decyloxy)benzaldoxime (2) as 1,3-dipole precursors (Figure 1). These long alkyl chain benzaldehyde precursors for long alkyl chain benzaldoxime $\mathrm{NH}$ nirone were easily synthesized by classical nucleophilic substitution between 4-hydroxy benzaldehyde and 1-brormononane or 1-bromodecane in high yields $(89 \%, 91 \%)$, respectively. The aldehydes were converted quantitatively to the corresponding 4-(nonyloxy)benzaldoxime (1) and 4-(decyloxy) benzaldoxime (2) by treatment of hydroxylamine.

As shown in Figure 2, the solution of 4-(nonyloxy)benzaldoxime (1) or 4-(decyloxy)benzaldoxime (2) and perfluoro2-methyl-2-pentene as a dipolarophile in ethanol was reacted 


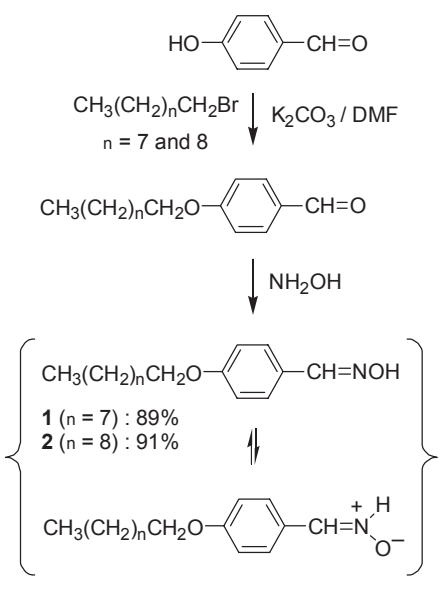

Figure 1. Synthesis of long alkyl chain substituent benzaldoximes (1 and 2) as a 1,3-dipole.
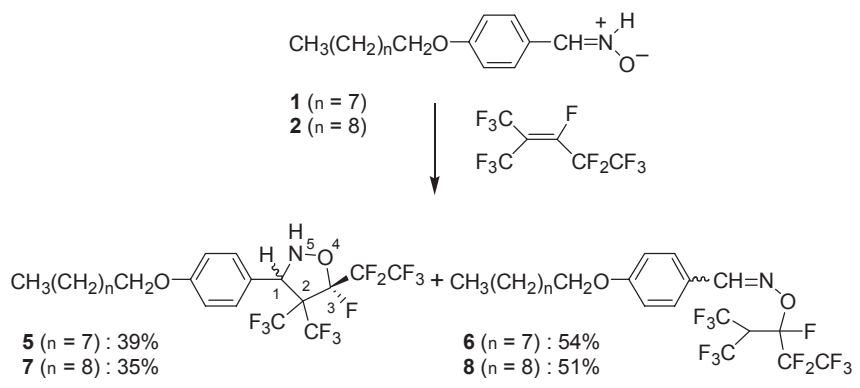

Figure 2. Regioselective synthesis of the isoxazolidine ( $\mathbf{5}$ and $\mathbf{7})$ and 1,2-addition compounds ( $\mathbf{6}$ and $\mathbf{8}$ ) by 1,3-dipolar cycloaddition between long alkyl chain benzaldoxime NH-nitrone and perfluoro-2methyl-2-pentene.

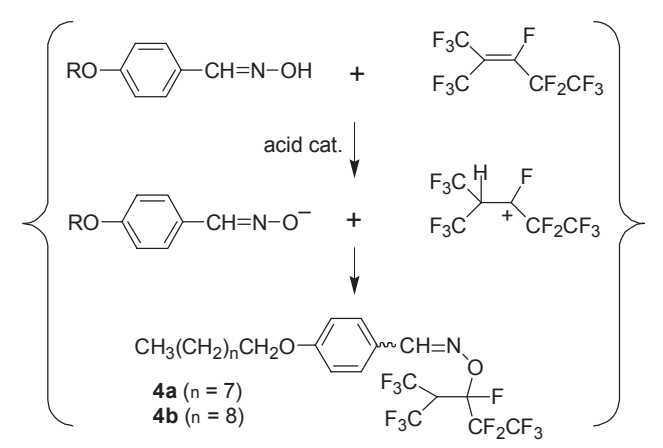

Figure 3. Proposed reaction pathway for 1,2-addition of the aldoxime group via an acid catalyzed carbocation intermediate.

under room temperature for $12 \mathrm{~h}$. The neutral long alkyl chain benzaldoxime ( $\mathbf{1}$ and $\mathbf{2})$ is expected to change into the $\mathrm{NH}-$ nitrone form via proton transfer from the $\mathrm{OH}$ to nitrogen atom (Figure 1), and then the resulting NH-nitrone species can smoothly be reacted with the perfluorinated olefin to provide the regioselective 1,3-dipolar cycloaddition isoxazolidine $5(39 \%)$, $7(35 \%)$ and 1,2-addition product $6(54 \%), 8(51 \%)$ in a high yield, respectively. Thus, the negative charged $N$-oxide species derived from tautomerization of the oxime was preferentially bonded with the positive charged olefin carbon atom.

The structural assignments of $\mathbf{5}$ and $\mathbf{7}$ were also confirmed by ${ }^{19} \mathrm{~F}-\mathrm{NMR}$, IR, and MASS analysis (see the experimental section). The molar ratio of two diastereomer of $\mathbf{5} \mathbf{a}$ and $\mathbf{5 b}(6: 4)$ was characterized by ${ }^{1} \mathrm{H}$ NMR analysis in an intensity ratio. The determination of stereochemistry of $\mathrm{C}_{1} \mathrm{H}$ ( $1 R$ form) of $\mathbf{5 a}$ (diastereomer of $\mathbf{5 b}$ ) was deduced on the basis of analytical spectroscopic data. Thus, stereochemistry of $\mathbf{5 b}$ ( $1 S, 3 S$ form) was fully characterized by ${ }^{1} \mathrm{H}$ and ${ }^{19} \mathrm{~F}$ NMR spectral data (see the experimental part in this manuscript and compared with that of the fully characterized isoxazolidine compound of the reference 8); for example, the structure and the absolute stereochemistry of the methine proton $\left(\mathrm{C}_{1} \mathrm{H}, 5.46 \mathrm{ppm}\right)$ in $\mathbf{5 a}$ was easily deduced to be " $R$ " form on the basis of the chemical shift of $\mathbf{5 b}$ ( $1 S$ form, $5.06 \mathrm{ppm}$ ) and the other characteristic ${ }^{1} \mathrm{H}$ NMR data of $\mathbf{5 a}$ were very similar with the $\mathbf{5 b}$.

The structural assignments of 1,2-addition products ( $\mathbf{6}$ and $\mathbf{8})$ can be easily assigned as trans-form (up-field shift, $4.46 \mathrm{ppm}$ around) and cis-form (down-field shift, $4.84 \mathrm{ppm}$ around), respectively. These stereochemical assignments were consistent, as analyzed by ${ }^{13} \mathrm{C}$ - and ${ }^{19} \mathrm{~F}-\mathrm{NMR}$, with previously studied perfluorinated isoxazolidine compounds ${ }^{8}$ characterized by X-ray crystallography and NMR (see the experimental data).

These results also demonstrate that NH-nitrone does indeed lead to clean generation of the nitronium oxide form and that this intermediate is more stabilized by electron rich substituent as a long alkyl chain group. We believe that the positively charged carbon atom due to inductive effect by the substituent of trifluoromethyl or pentafluoroethyl group in perfluorinated olefin prefers the formation of 3-substituted regioisomers uniting the larger coefficients in the transition state with negative oxygen atom. From a mechanistic point of view, the configuration of $\mathrm{C}_{3}$ (5-menbered heterocycle) of diastereomric mixtures 5 and 7 can be assigned to the $S$ configuration. These results of the $S$ configuration indicate that the approach of pentafluoroethyl group of olefin apart from the aromatic group of trans $\mathrm{NH}$-nitrone is more favored thereby leading to the preferential attack on this coordination to give the $S$-configuration of cycloaddition products ( $\mathbf{5}$ and $\mathbf{7})$.

To investigate the mechanistic processes of the 1,2-addition products ( 6 or 8 ), we explored cycloaddition reaction under the acidic chloroform solvent. Interestingly, 1,2-addition product 6 was slightly increased in a yield $(64 \%)$, while the isoxazolidine adduct was produced in a lower yield (27\%). Presumably, this means that 1,2-addition product can be produced via carbocation intermediate obtained by acid catalyzed protonation to the double bond of perfluoro-2-methyl-2-pentene. Thus, more negatively charged carbon atom of the double bond of perfluoro-2-methyl-2-pentene can be catalyzed and protonated by acidic species to give the corresponding carbocation intermediate, as a result, 1,2-addition process under chloroform can be more prevailed than the case of less acidic ethanol solvent (Figure 3).

The next key issue was to synthesize the regioselective perfluorinated isoxazoline compounds by 1,3-dipolar cycloaddition between perfluorinated nitrile oxide and non-fluorinated olefin compound such as a styrene. In order to do so, we prepared $1 \mathrm{H}, 1 \mathrm{H}, 2 \mathrm{H}, 2 \mathrm{H}$-perfluoro-1-nonanaldoxime (4) as the 1,3-dipole 


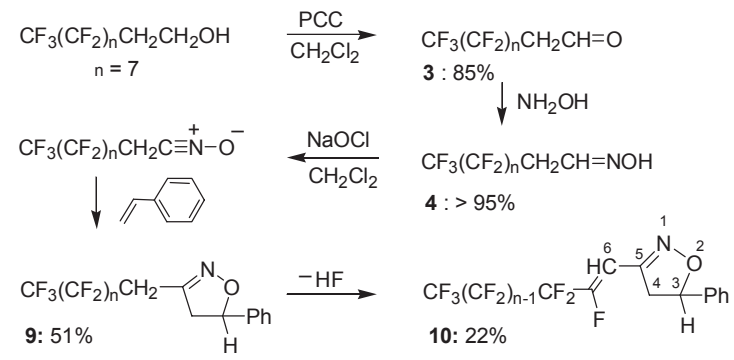

Figure 4. Synthesis of perfluorinated long alkyl chain isoxazoline (9) and de-hydrofluorinated isoxazoline $\mathbf{1 0}$ derived from the compound 9.

(Figure 4). The perfluorinated primary decanol, $1 \mathrm{H}, 1 \mathrm{H}, 2 \mathrm{H}, 2 \mathrm{H}$ perfluoro-1-decanol, was readily oxidized into the corresponding $1 \mathrm{H}, 1 \mathrm{H}, 2 \mathrm{H}, 2 \mathrm{H}$-perfluoro-1-nonanal in a yield $(57 \%)$ by treatment with pyridinium chlorochromate (PCC). The $1 H, 1 H$, $2 \mathrm{H}, 2 \mathrm{H}$-perfluoro-1-nonanal was quantitatively converted into the corresponding long alkyl chain $1 \mathrm{H}, 1 \mathrm{H}, 2 \mathrm{H}, 2 \mathrm{H}$-perfluoro-1nonanaldoxime (4) by treatment with hydroxylamine. When the compound $\mathbf{6}$ was treated with sodium hyphochlorite solution (2.0 equiv) in dichloromethane at room temperature for $30 \mathrm{~min}$, the resulting nitrile oxide intermediate as a 1,3-dipole was obtained. The in situ generated nitrile oxide intermediate (ca. $0.1 \mathrm{~mol}$ ) in chloroform was then treated with styrene as the dipolarophile $(0.3 \mathrm{~mol})$ to give the corresponding isoxazoline $9(51 \%)$ or $\mathbf{1 0}(22 \%)$ in a high yield, respectively (Figure 4$)$. The structure of compound 9 was easily determined by analysis of the ${ }^{1} \mathrm{H}-,{ }^{13} \mathrm{C}$-, and ${ }^{19} \mathrm{~F}-\mathrm{NMR}$ spectra and chemical evidence (see the experimental section). Interestingly, we also observed the de-hydrofluorinated isoxazoline adduct $\mathbf{1 0}$ derived from compound 9 in this cycloaddition. The structure of compound $\mathbf{1 0}$ was deduced to be the trans isomer on the basis of the signal patterns of 3-H (dd, $5.43 \mathrm{ppm}), 4-\mathrm{H}_{2}$ (dd, $\left.3.23 \mathrm{ppm}, 3.71 \mathrm{pm}\right)$, $6-\mathrm{H}(\mathrm{d}, 6.57 \mathrm{ppm})$, and aromatic- $\mathrm{H}_{5}$. We believe that the conjugated structure $\mathbf{1 0}$ (or de-hydrofluorinated form) is more stable than the nonconjugated structure 9 . As a result, we think that the 9 can easily be converted into the de-hydrofluorinated form during the isolation process by the acidic column chromatography condition. It must be added that, to the best of our knowledge, only an extended double bond isoxazoline in per- fluorinated heterocyclic compounds has been described in this literature.

\section{Conclusions}

In conclusion, we have demonstrated a useful and general 1,3-dipolar cycloaddition synthetic route between NH nitrone or nitrile oxide and olefin to give the regioselective perfluorinated long alkyl chain heterocyclic compounds. The reaction pathway generating heterocyclic compounds and addition products can be controlled by the acidic solvent media. We believe that this methodology could be applied not only to an efficient regioselective heterocyclic compound preparation of a wide variety of perfluorinated long alkyl chain systems but also to the study of potential SAM chemistry by interactions such as hydrogen bonding, F-F interactions, and van der Waals forces. Extension of the present strategy to other intermolecular reactions and a study of SAM properties of the prepared perfluorinated alkyl-heterocycles are currently in progress.

Acknowledgments. This work was supported by Priority Research Centers Program through the National Research Foundation of Korea (NRF) funded by the Ministry of Education, Science and Technology (2009-0093818). This work has been supported by the WCU research fund (R33-2008-000-10003) carried out in the Department of Chemistry, University of Ulsan.

\section{References}

1. Motomatsu, M.; Mizutani, W.; Nie, H.-Y.; Tokumoto, H. Thin Solid Films 1996, 548, 281.

2. Graupe, M.; Koini, T.; Wang, V. Y.; Nassif, G. M.; Colorado, R. Jr.; Villazana, R. J.; Dong, H.; Miura, Y. F.; Shmakova, O. E.; Randall Lee, T. J. Fluorine Chem. 1999, 93, 107.

3. Bruche, L.; Arnone, A.; Bravo, P.; Panzeri, W.; Pesenti, C.; Viani, F. Eur. J. Org. Chem. 1999, 1665.

4. Burger, K.; Wucherpfennig, U.; Brunner, E. Adv. Heterocycl. Chem. 1994, 60, 1 .

5. Buscemi, S.; Pace, A.; Pibiri, I. Vivona, N.; Carona, T. J. Fluorine Chem. 2004, 125, 165.

6. Yildirim, A.; Cetin, M. Corros. Sci. 2008, 50, 155.

7. Torssell, K. B. G. Nitrile Oxides, Nitrones and Nitronates in Organic Synthesis; VCH: New York, 1988.

8. Lee, C. W.; Park, J. Y.; Kim, H.; Chi, K.-W. Bull. Korean Chem. Soc. 2009, 31, 1179. 